\title{
Updating Standard Operating Procedures : Tuntutan Manajemen? Studi Kasus Pada Unit Gizi Rumah Sakit X Di Surabaya
}

\author{
Lidya Ratnasari Tejosaputra ${ }^{1}$, Hendra Wijaya ${ }^{2}$
}

\author{
Program Magister Akuntansi Sekolah Pascasarjana Universitas Katolik Widya Mandala Surabaya \\ Jl. Dinoyo No. 48A, Keputran, Tegalsari - Surabaya
}

\author{
A R T I C L E I N F O \\ Article history: \\ Received 29 Oktober 2018 \\ Revised 12 November 2018 \\ Accepted 21 November 2018
}

Key words:

Hospital, Nutrition Unit, Standard

Operational Procedures (SOP), SOP

Change, and Change of Management

\begin{abstract}
A B S T R A C T
The purpose of this study is to analyze and evaluate the implementation of standard operational procedures (SOPs) in nutrition unit of X hospital in Surabaya after the change of management. The scope of the study is the implementation of SOPs that focused on the organizing of processing food in hospital's kitchen. The study uses explanative qualitative approach with case study method. The types and sources of data are qualitative and primary data. Methods of data collection are interview, observation, and documentation.

The results of the study show that the change of management caused many changes and adjustments in day to day operational implementation, but there is not enough updating the SOPs. The evaluation of SOPs reveals that the report needed by new management is not available as there are not enough documents in the existing SOPS to support the availability of the report. Hence, the updating of SOPs is necessary to fulfill the management demand.
\end{abstract}

\begin{abstract}
A B S T R A K
Penelitian ini bertujuan untuk menganalisis dan mengevaluasi pelaksanaan prosedur operasional standar (POS) pada unit gizi Rumah Sakit (RS) X Surabaya pasca pergantian manajemen. Ruang lingkup penelitian ini adalah pelaksanaan POS pada unit gizi RS X di Surabaya yang berfokus pada prosedur penyelenggaraan makanan olahan dapur. Penelitian ini menggunakan pendekatan kualitatif eksplanatif dengan metode studi kasus. Jenis dan sumber data berupa data kualitatif dan data primer. Metode pengumpulan data menggunakan wawancara, observasi, dan dokumentasi; serta teknik analisis data menggunakan metode studi kasus.

Hasil penelitian menunjukkan bahwa pergantian manajemen mengakibatkan banyaknya perubahan dan penyesuaian dalam pelaksanaan operasional sehari-hari, namun tidak diimbangi dengan pembaruan POS. Hasil evaluasi POS menunjukkan ketidaktersediaan laporan yang diminta oleh manajemen baru karena dokumen tersebut tidak tercantum pada POS yang ada. Oleh karena itu, pembaharuan POS merupakan hal penting untuk memenuhi tuntutan manajemen.
\end{abstract}

\section{INTRODUCTION}

Institusi pelayanan kesehatan yang menyelenggarakan pelayanan kesehatan perorangan secara paripurna yang menyediakan pelayanan rawat inap, rawat jalan, dan gawat darurat adalah pengertian rumah sakit menurut Pasal 1 ayat 1 Undang-Undang Republik Indonesia Nomor 44 Tahun 2009 tentang Rumah Sakit. Jasa layanan kesehatan ini terus mengalami perkembangan dalam kurun waktu beberapa tahun terakhir. Hingga tahun 2016, terdapat 2.601 rumah sakit yang tersebar di Indonesia berdasarkan data dari Kementerian Kesehatan Republik Indonesia (Budijanto, 2017). Peningkatan jumlah rumah sakit ini juga harus diimbangi dengan peningkatan mutu pelayanan dan tata kelola. Prosedur setiap aktivitas dibutuhkan oleh rumah sakit dalam pelaksanaan pelayanan dan tata kelola manajemen tersebut. Dalam lingkup bisnis, prosedur-prosedur tersebut bisasanya disebut dengan Prosedur Operasional Standar (POS) (Fatimah, Jenar, Arditya, Alviani, 2015:46).

POS adalah sekumpulan manual pekerjaan yang mencerminkan langkah-langkah aktivitas, arus data, dan personil yang mengerjakannya dalam suatu organisasi (Purba, 2014:37). Menurut Soemohadiwidjojo (2015), POS merupakan panduan yang digunakan untuk memastikan 
kegiatan operasional organisasi atau perusahaan berjalan lancar. Sedangkan menurut Purnamasari (2015), POS adalah prosedur kerja yang dibuat secara terperinci bagi semua karyawan untuk melaksanakan pekerjaan sebaik-baiknya sesuai dengan misi, visi, dan tujuan suatu lembaga, instansi, atau perusahaan. Dengan kata lain, POS bisa dijadikan suatu pedoman dalam menjalankan aktivitas rumah sakit terutama dalam bagian pemisahan tugas dan tanggung jawab. POS akan menerangkan alur proses suatu kejadian, dalam hal ini ialah alur proses penerimaan pasien baik pasien rawat inap dan rawat jalan, pendukung pelayanan pasien seperti pemberian asupan gizi untuk membantu pemulihan kondisi pasien khusus pasien rawat inap, hingga pembuatan laporan keuangan rumah sakit. Salah satu tujuan penyusunan POS adalah memperjelas alur tugas, wewenang serta tanggung jawab setiap unit kerja (Fatimah dkk, 2015:51). POS juga berkaitan dengan ketersediaannya dokumen tertulis yang memuat prosedur kerja rinci, tahap demi tahap dan sistematis. Kriteria Prosedur Operasional Standar yang baik menurut Tambunan (2008 : 79-80) yaitu efektif, efisien, konsisten, standar dan sistematis. Untuk melengkapi suatu prosedur kerja, POS juga sering dilengkapi dengan referensi, lampiran, diagram atau alur kerja / flowchart (Rahman, 2003). Flowchart juga dapat digunakan untuk merancang sistem yang baru untuk menutupi kelemahan yang ada (Zulfikar, 2012). Sebaiknya dalam penyusunan POS harus disusun tahap demi tahap dan tersistem dengan baik serta terperinci dan mengandung unsur-unsur POS. Terdapat 10 unsur-unsur POS menurut Tambunan (2008:120-143) antara lain terdapat tujuan, kebijakan, petunjuk operasional, pihak yang terlibat, formulir, masukan, proses, laporan, validasi, dan kontrol.

Rumah sakit yang sedang dalam perkembangan akan banyak membutuhkan masukan untuk meningkatkan kualitas rumah sakit salah satunya adalah mengenai POS tersebut. Rumah sakit yang sedang dalam perkembangan saat ini yaitu Rumah Sakit X (RS X) di Surabaya. Perkembangan rumah sakit tersebut diikuti dengan pergantian manajemen yang terlihat sangat optimis dan antusias dalam hal pengembangan rumah sakit. Saat ini RS $X$ sedang berorientasi pada perbaikan POS unit gizi. Unit gizi RS $X$ ialah salah satu unit pada Bidang Penunjang Medis. Unit ini berlokasi di dapur RS X dan aktivitas dalam keseharian di dapur dilaksanakan oleh ahli gizi dan petugas dapur. Adapun macam-macam pelaksanaan di dapur antara lain pembelian bahan maka- nan, pengolahan bahan makanan, penyimpanan bahan makanan, pencucian alat makanan, hingga pendistribusian bahan makanan dan penerimaan bahan makanan, baik makanan pasien, makanan penjaga pasien, dan makanan karyawan lembur, serta pelaksanaan lainnya. Pihak-pihak yang terkait pada pelaksanaan kegiatan operasional tidak hanya dari ahli gizi dan karyawan dapur, namun juga melibatkan pihak dari bidang-bidang lain yang berkaitan seperti bagian pengadaan untuk pembelian bahan makanan, unit rawat inap yakni perawat jaga yang memberikan daftar jumlah pasien inap dan penjaga pasien untuk permintaan makan, dan sebagainya.

Pendokumentasian kegiatan harian merupakan hal penting untuk dilakukan dalam setiap unit kerja. Pendokumentasian dapat dilakukan dalam bentuk pencatatan transaksi setiap kejadian dalam unit kerja khususnya unit gizi, seperti pencatatan pembelian bahan makanan, pencatatan kuantitas hasil olahan makanan, pencatatan pendistribusian makanan, dan sebagainya. Pencatatan tersebut dapat berguna sebagai arsip dan bukti setiap pelaksanaan untuk tujuan pengendalian internal, memastikan bahwa pelaksanaan di lapangan telah sesuai dengan POS yang berlaku, dan dapat mempermudah pihak yang membutuhkan penelusuran apabila ditemukan perubahan-perubahan yang terjadi seperti perubahan harga dan sebagainya, ataupun ditemukan sebuah kejadian yang kurang wajar.

Peninjauan awal pada unit gizi RS $X$ di Surabaya telah dilakukan peneliti dan ditemukan bahwa terdapat beberapa dokumen yang belum tersedia, salah satunya adalah ketika ada permintaan manajemen RS X yang baru akan sebuah laporan rekap harian data tersebut tidak dapat tersedia sehingga tidak dapat dipenuhi oleh dan hal ini mempengaruhi pimpinan RS $X$ dalam mengambil keputusan dalam hal keuangan RS $X$ untuk unit gizi tersebut. Namun pada POS memang tidak tercantum adanya prosedur yang meminta pembuatan laporan rekap harian tersebut. Hal ini mengindikasikan bahwa POS yang terdapat pada RS X perlu dievaluasi dan dilakukan pembaruan (updating) melihat situasi perkembangan jaman saat ini yang kian berubah khususnya perkembangan dan perubahan dari manajemen yang baru, sehingga menuntut RS X untuk menyesuaikan diri dengan permasalahanpermasalahan yang timbul secara alami dari situasi yang saat ini sedang berjalan. Salah satu bentuk dari upaya penyesuaian diri ialah dengan mengevaluasi POS. Sebelum mengevaluasi POS, penerapan pelaksanaan POS juga harus terus 
menerus dipantau / diawasi (monitoring) sehingga proses penerapan POS nya dapat berjalan dengan baik sehingga apabila terdapat masukan dalam setiap pelaksanaan monitoring, hal ini dapat digunakan sebagai bahan dalam evaluasi POS sehingga dapat dilakukan pembaharuan secara tepat sesuai kebutuhan.

Perubahan lingkungan organisasi dapat membawa pengaruh pada POS yang telah ada. Oleh karena itu, dibutuhkan evaluasi POS secara terus menerus agar prosedur-prosedur di organisasi selalu merujuk pada akuntabilitas dan kinerja yang baik. Sesuai dengan hasil penelitian Marbun (2013), POS dapat berjalan efektif jika para pemimpinnya mulai dari kepala, manajer, hingga direktur secara rutin melakukan pengendalian terhadap POS. Pengendalian POS dapat dilakukan melalui supervisi dan evaluasi. Supervisi dapat dilakukan membandingkan kinerja dengan POS yang ada sehingga apabila terdapat permasalahan yang memerlukan pembaharuan POS dapat dilakukan penyesuaian ulang. Berbeda dengan hasil wawancara awal dengan ahli gizi RS X. POS yang dipakai sebagai pedoman pelaksanaan operasional RS X saat ini adalah POS yang diterbitkan tahun 2015. Kurang lebih 2 tahun POS tersebut belum pernah dilakukan proses monitoring. Kurang adanya keterlibatan dari pimpinan dalam pengendalian POS melalui supervisi dan evaluasi lalu ditambah dengan adanya tuntutan manajemen yang baru akan pembuatan suatu laporan tertentu membuat POS dirasa perlu untuk dilakukan evaluasi dan pembaharuan. Berdasarkan penemuan tersebut, penelitian ini berupaya untuk menjawab pertanyaan umum yaitu: bagaimana pelaksanaan POS pada unit gizi RS $X$ di Surabaya?". Pertanyaan umum tersebut dijabarkan dalam pertanyaan rinci sebagai berikut: pertama, bagaimana penerapan POS pada Unit Gizi RS X di Surabaya? Kedua, bagaimana evaluasi penerapan POS pada Unit Gizi RS X di Surabaya? Dan ketiga, perbaikan apa saja yang dibutuhkan untuk melakukan pembaharuan POS? Sedangkan tujuan khusus dalam penelitian ini yaitu untuk menganalisis dan mengevaluasi penerapan POS pada Unit Gizi RS X di Surabaya sehingga dapat memperbarui POS pada Unit Gizi RS X di Surabaya dan akhirnya kinerja RS X yang optimal dapat tercapai. Sedangkan tujuan umum dari penelitian ini adalah untuk menilai keefektifan dan efisiensi pelaksanaan kegiatan unit gizi yang fokus pada prosedur penyelenggaraan makanan olahan dapur. Penyelenggaraan makanan olahan yang dimaksud ialah dimulai dari proses perencanaan kebutuhan bahan makanan, pemesanan bahan makanan, pembelian bahan makanan, penerimaan bahan makanan, pengolahan bahan makanan, pendistribusian makanan pasien, hingga penyajian makanan pasien.

Hasil penelitian ini diharapkan dapat memberikan manfaat secara akademik yakni dengan membuktikan bahwa POS sangat penting membuktikan bahwa melalui updating POS, permasalahan yang terjadi pada Unit Gizi RS X di Surabaya dapat berkurang sehingga kinerja unit gizi dapat terus meningkat dan pada akhirnya penerapan POS yang efektif dan optimal dapat berjalan di RS X. Dan hasil penelitian ini juga diharapkan dapat memberikan manfaat secara praktik bagi Unit Gizi RS X di Surabaya berupa saran perbaikan, masukan, atau solusi yang diberikan kepada Unit Gizi RS X di Surabaya untuk dapat melakukan pembaharuan POS unit gizi menyesuaikan dengan perubahan-perubahan yang terjadi khususnya pada saat pergantian manajemen jika diperlukan.

\section{THEORETICAL FRAMEWORK}

Internal Control Berdasarkan Rerangka Konseptual Committee of Sponsoring Organizations (COSO)

Pada tahun 1992, COSO mendefinisikan pengendalian internal sebagai keterlibatkan dewan komisaris, manajemen, dan personil lain dalam sebuah proses yang dirancang untuk memberikan keyakinan memadai tentang pencapaian 3 tujuan yakni efektivitas dan efisiensi operasi, keandalan pelaporan keuangan, dan kepetuhan kerhadap hukum dan peraturan yang berlaku (Bodnar \& Hopwood. 2013:108). Komponen-komponen pengendalian internal menurut COSO antara lain lingkungan pengendalian, aktivitas pengendalian, pengukuran risiko, informasi dan komunikasi, serta pengawasan (Krismiaji, 2010:223).

\section{Komponen Internal Control Menurut Rerangka Konseptual COSO}

5 komponen COSO yang saling terkait yakni:

1) Lingkungan Pengedalian

Tulang punggung sebuah perusahaan adalah karyawan yang meliputi atribut individu, seperti integritas, nilai etika dan kompetensi; serta lingkungan tempat karyawan tersebut bekerja. Karyawan merupakan mesin penggerak organisasi dan merupakan fondasi untuk komponen lainnya.

2) Aktivitas pengendalian

Perusahaan harus menetapkan prosedur dan kebijakan pengendalian dan melaksanakannya 
untuk membantu menjamin bahwa manajemen dapat menetapkan tindakan-tindakan yang diperlukan untuk menghadapi ancaman-ancaman yang muncul, sehingga tujuan organisasi dapat dicapai secara efektif.

3) Pengukuran risiko

Organisasi harus menyadari dan waspada terhadap berbagai risiko yang dihadapinya. Oleh karena itu, perusahaan harus menetapkan serangkaian tujuan, yang terintegrasi dengan kegiatan penjualan, produksi, pemasaran, keuangan, dan kegiatan lainnya sehingga organisasi dapat beroperasi sebagaimana mestinya organisasi harus pula menetapkan mekanisme untuk mengidentifikasi, menganalisis, dan mengelola risiko-risiko terkait.

4) Informasi dan komunikasi

Sistem informasi dan komunikasi mengitari kegiatan pengawasan. Sistem tersebut memungkinkan karyawan organisasi untuk memperoleh dan menukar informasi yang dibutuhkan untuk melaksanakan, mengelola dan mengendalikan kegiatan organisasi.

5) Pengawasan

Seluruh proses bisnis harus diawasi dan dilakukan modifikasi seperlunya. Dengan cara ini, sistem akan berinteraksi secara dinamis, yaitu berubah jika kondisinya menghendaki perubahan.

Berdasarkan pada 5 komponen tersebut, komponen yang paling sesuai untuk dipakai dalam penelitian ini adalah komponen aktivitas pengendalian. Dalam aktivitas pengendalian, perlu ditetapkan sebuah prosedur yang tertulis untuk menjamin bahwa manajemen dapat menentukan tindakan yang tepat agar tujuan organisasi dapat dicapai secara efektif yakni Prosedur Operasional Standar (POS).

\section{Prosedur Operasional Standar (POS)}

1) Definisi POS

Berikut adalah beberapa pengertian POS menurut beberapa sumber :

a. Menurut Fatimah dkk (2015:49), POS adalah pedoman tertulis yang berisi serangkaian prosedur kerja operasional suatu organisasi agar berjalan efektif, serta mencapai sasaran yang telah ditetapkan.

b. Menurut Purba (2014:37), POS adalah sekumpulan manual pekerjaan yang mencerminkan langkah-langkah aktivitas, arus data, dan personil yang mengerjakannya dalam suatu organisasi

c. Menurut Purnamasari (2015:13), POS adalah prosedur kerja yang dibuat secara detail dan terperinci bagi semua karyawan untuk melaksanakan pekerjaan dengan sebaik-baiknya sesuai dengan misi, visi, dan tujuan suatu lembaga, istansi, atau perusahaan.

d. Menurut Soemohadiwidjojo (2015:11), POS merupakan panduan yang digunakan untuk memastikan kegiatan operasional organisasi atau perusahaan berjalan dengan lancar.

Berdasarkan pengertian-pengertian POS di atas, maka dapat diringkas bahwa POS ialah sekumpulan pedoman tertulis yang berisi serangkaian kerja operasional yang dibuat secara detail dan terperincibagi semua karyawan agar berjalan efektif sesuai dengan misi, visi, dan tujuan suatu perusahaan.

2) Tujuan dan Fungsi POS

Ada berbagai macam tujuan dan fungsi dari dibuatnya sebuah POS untuk perusahaan dan juga untuk koperasi. Menurut Purnamasari (2015:16-17), tujaun dan fungsi dari dibuatnya POS antara lain memberikan sebuah rekaman kegiatan dan pengoperasiannya secara praktis; mengetahui dengan jelas peran dan fungsi tiap-tiap posisi dalam organisasi; membentuk kedisiplinan kepada semua anggota organisasi baik dalam institusi, organisasi maupun perusahaan; menjaga tingkat kinerja yang konsisten pada masing-masing unit kerjanya; memperlancar pekerjaan atau tugas bagi karyawan, sebagai dasar hukum yang kuat untuk mengambil tindakan ketika ada penyelewengan/ penyalahgunaan wewenang; memberikan kemudahan dalam menyaring, menganalisis, dan membuang hal-hal atau pekerjaan yang tidak sesuai dengan prosedur; untuk meminimalkan kesalahan/ kegagalan, keraguan, duplikasi, dan inefisiensi; memperbaiki kualitas atau performa karyawan itu sendiri; membantu menguatkan regulasi perusahaan; memastikan efisiensi tiap-tiap aktivitas operasional; menjelaskan segala peralatan untuk keefektifan program pelatihan; memberikan kemudahan dalam melaksanakan pekerjaan sehingga semua karyawan menyadari akan tanggung jawab pekerjaan, memahami, dan mengetahui hak dan kewajibannya; serta melindungi organisasi/unit kerja dan karyawan dari malapraktik atau kesalahan lainnya.

3) Manfaat POS

Menurut Fatimah dkk (2015:52-53), manfaat dari POS yakni: meminimalisir kesalahan dalam melakukan pekerjaan; mempermudah serta menghemat waktu dan tenaga dalam program training karyawan; sebagai sarana untuk mengkomunikasikan pelaksanaan suatu pekerjaan; menjadi acuan dalam melakukan penilaian 
terhadap proses layanan; mempermudah tahapan pelayanan yang diberikan kepada masyarakat sebagai konsumen; pegawai menjadi lebih mandiri dan tidak tergantung pada intervensi manajemen; mengurangi beban kerja serta dapat meningkatkan comparability, credibility, dan defensibility; menjadi alat komunikasi antara pelaksana dan pengawas, serta membuat pekerjaan diselesaikan secara konsisten; membantu dalam melakukan evaluasi dan penilaian terhadap setiap proses operasional perusahaan; membantu mengendalikan dan mengantisipasi apabila terjadi perubahan suatu kebijakan; mempertahankan kualitas perusahaan melalui konsistensi kerja karena perusahaan telah memiliki sistemkerja yang sudah jelas dan terstruktur secara sistematis; serta menjadi dokumen aktivitas proses bisnis perusahaan.

POS bermanfaat untuk meminimalisir kesalahan karena menjelaskan secara rinci setiap pekerjaan yang harus dilakukan oleh setiap pekerja dan bermanfaat sebagai alat evaluasi untuk mengetahui apakah setiap proses operasional dalam perusahaan telah berjalan dengan baik atau belum.

\section{Kerangka Penelitian

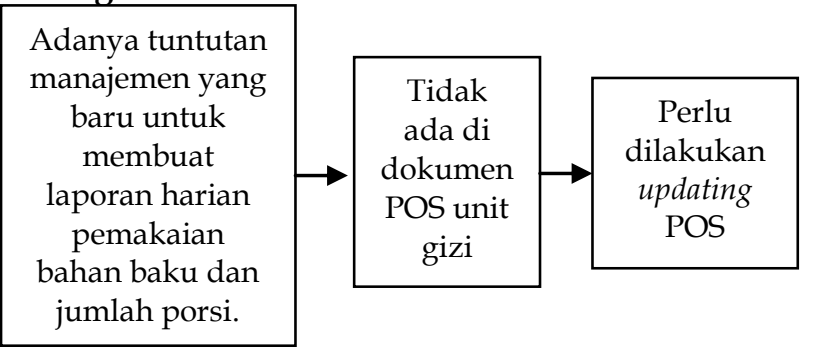

\section{RESEARCH METHODS \\ Jenis Penelitian}

Jenis penelitian yang digunakan dalam penelitian ini adalah penelitian kualitatif eksplanatif dengan metode studi kasus. Penelitian eksplanatif bertujuan untuk mencari tahu dan memberikan penjelasan secara rinci bagaimana tuntutan manajemen yang baru dan POS yang belum diperbarui dapat mempengaruhi pengambilan keputusan.

\section{Objek Penelitian}

Objek penelitian dalam penelitian ini adalah unit gizi Rumah Sakit $X$ di Surabaya.

\section{Jenis dan Sumber Data}

Jenis data yang akan digunakan dalam penelitian ini berupa data kualitatif. Data kualitatif yaitu data yang berhubungan dengan aktivitas operasional sehari-hari dari unit gizi ini. Sumber data primer yang diperoleh secara internal dari unit gizi (ahli gizi dan karyawan dapur)

Alat dan Metode Pengumpulan Data

Alat pengumpulan data yang digunakan dalam penelitian ini adalah daftar pertanyaan dan recorder untuk merekam wawancara dengan internal dari unit gizi (2 orang ahli gizi, 2 orang karyawan dapur, dan 2 orang perawat). Peneliti mengambil 6 informan tersebut karena adanya keterlibatan langsung dalam aktivitas pengendalian dan pelaksana operasional unit gizi. Selain itu, alat pengumpulan data lainnya adalah kamera video untuk merekam aktivitas operasional unit gizi. Data-data yang diperlukan dikumpulkan melalui beberapa cara, yaitu: wawancara, observasi, dan dokumentasi. Wawancara dilakukan dengan bentuk semi-structured interview dengan tatap muka, telepon, dan mekanisme online lainnya yang bertujuan untuk mengetahui aktivitas pengendalian pada unit gizi. Observasi dilakukan untuk mengetahui aktivitas apa saja yang dilakukan oleh internal unit gizi dan memastikan validitas data yang diperoleh dari wawancara dan dokumentasi. Observasi dilakukan dengan metode participant observation karena peneliti terlibat dalam kegiatan operasional rumah sakit $X$. Dokumentasi yang diperlukan meliputi POS unit gizi, buku makan dan diet yang berisi daftar rincian makanan serta diet masing-masing pasien, daftar siklus menu dan spesifikasi bahan, formulir permintaan belanja bahan dapur, laporan ketepatan waktu pendistribusian makanan, buku rekap makan pasien, dan sebagainya yang mendukung analisis aktivitas pengendalian di unit gizi.

\section{Teknik Analisis Data}

Teknik analisis data menggunakan metode studi kasus pada unit gizi rumah sakit $X$ di Surabaya.

\section{DATA ANALYSIS AND DISCUSSION}

Berikut adalah uraian hasil dokumentasi peneliti mengenai POS yang merupakan detail proses di setiap aktivitas dalam penyelenggaraan makanan olahan dapur.

\section{Standard Operating Procedures (POS) pada Unit Gizi Rumah Sakit X di Surabaya}

1) Prosedur perencanaan kebutuhan bahan makanan meliputi penyusunan macam bahan makanan yang diperlukan, lalu golongkan bahan makanan menjadi 2 yaitu bahan makanan basah dan bahan makanan kering; Penetapan jumlah pasien rata-rata yang dilayani tiap harinya; Perhitungan macam dan kebutuhan makanan dalam 1 kali siklus; Penetapan kurun waktu kebutuhan bahan makanan; Perhitun- 
gan berapa kali siklus dalam 1 periode yang telah ditetapkan dan perhitungan macam kebutuhan serta jumlah bahan makanan untuk kurun waktu yang ditetapkan; dan terakhir melakukan proses pencatatan dalam formulir kebutuhan bahan makanan.

2) Prosedur pemesanan bahan makanan dimulai dari pembuatan daftar kebutuhan bahan makanan yang dilakukan setiap hari untuk bahan makanan basah dan bahan makanan kering; Pemberikan daftar bahan makanan kepada rekanan; Penetapkan waktu penerimaan bahan makanan sesuai kesepakatan; dan terakhir dilakukan proses pencatatan (dokumentasi form pemesanan bahan makanan).

3) Prosedur pembelian bahan makanan antara lain dengan menentukan kebutuhan bahan makanan berdasarkan siklus menu dan jumlah pasien; Melaporkan kepada pihak rekanan; Menentukan spesifikasi bahan makanan; dan mmenentukan harga bahan makanan sesuai dengan harga pasar pada saat perjanjian dengan pihak rekanan.

4) Prosedur penerimaan bahan makanan yaitu dimulai dari setiap petugas penerimaan bahan makanan membawa daftar spesifikasi bahan makanan; Bahan makanan yang datang harus dicocokkan dengan daftar pesanan dan daftar spesifikasi bahan makanan apakah sudah sesuai dengan jenis, berat, jumlahnya dan spesifikasi. Apabila bahan makanan yang dikirim tidak sesuai dengan spesifikasi bahan makanan yang ditentukan harus dikembalikan pada rekanan untuk ditukar dengan bahan makanan dengan jenis yang sama tetapi sesuai spesifikasi; dan pada akhirnya melakukan pencatatan (dokumentasi form penerimaan bahan makanan)

5) Prosedur pengolahan bahan makanan meliputi dari pengolahan nasi dan tim, pengolahan bubur kasar, pengolahan bubur halus, pengolahan lauk hewani, pengolahan lauk nabati, dan pengolahan sayur

6) Prosedur distribusi makanan pasien dilaksanakan secara sentralisasi oleh petugas pramusaji Instalasi gizi rumah sakit. Dalam pendistribusian diperlukan adanya standar pemberian makanan rumah sakit; standar porsi yang ditetapkan unit gizi rumah sakit; peraturan pengambilan makanan; adanya bon permintaan makanan dari ruang rawat inap; adanya Daftar Makan Pasien (DMP) yang mencantumkan kelas perawatan, no rekam medis, nama pasien, jenis diet dan keterangan yang berkenaan dengan dietnya; adanya daftar makanan sesuai ketentuan diit/kebutuhan pasien; Tersedianya kelengkapan peralatan makan untuk pasien VVIP, VIP, Utama menggunakan Bento dan kelas (1,2 dan 3) menggunakan dinner set; Tersedianya sarana untuk distribusi makanan dan tenaga pramusaji serta jadwal distribusi makanan. Prosedur distribusi makanan dimulai dari petugas pramusaji yang membagi/memorsi makanan sesuai standar porsi dan jenis diet ke dalam Bento untuk pasien VVIP, VIP dan Utama dan alat saji yang sesuai dengan fungsinya untuk pasien kelas 1,2,dan 3 berdasarkan DMP dari masing-masing ruang rawat inap; selajutnya petugas pramusaji menutup alat saji yang terisi makanan dengan plastik kemas lalu menuliskan label berisi nama pasien, jenis diet, no rekam medis dan ruangan dan menempelkannya pada baki alat makan masingmasing; Ahli gizi memeriksa nama pasien, porsi, dan jenis diet pasien dan jika sudah diperiksa, petugas pramusaji memasukan kedalam kereta dorong; Petugas pramusaji mengantar makanan pada jadwal yang telah ditentukan dan menyerahkan diet/makanan hingga sampai ke pasien; tidak Petugas pramusaji menyampaikan ke pasien tentang kelengkapan alat makan (pasien VVIP, VIP, Utama, kelas 1, kelas 2, dan kelas 3).

7) Prosedur penyajian makanan pasien dilakukan dan dimulai dengan cara melihat buku makan pasien dan diet pasien; Menanyakan kepada perawat jaga apakah ada pasien baru yang memerlukan diet baru/makan; Menanyakan kepada perawat jaga apakah ada pasien yang puasa laborat,puasa operasi; Membawa baki makan pasien ke ruang rawat; Memperkenalkan diri kepada pasien yang dimaksud; Menanyakan nama pasien yang dimaksud; Meminta ijin untuk mencocokkan nama pasien dengan nama yang tertera di gelang pasien; Memberikan makanan kepada pasien atau meletakkan di meja pasien dan mempersilahkan pasien untuk makan.

\section{Hasil Observasi Penerapan POS di Lapangan}

Berikut adalah uraian hasil observasi setiap aktivitas dalam penyelenggaraan makanan olahan dapur berdasarkan hasil wawancara dengan ahli gizi dan petugas dapur, serta berdasarkan observasi peneliti:
1) Proses perencanaan kebutuhan bahan makanan: 
Pada sore hari ketika petugas dapur mengantar makanan pasien, perawat memberikan Buku Makan dan Minum lantai 3 dan lantai 4 yang berisi jumlah pasien, nomor kamar, nama pasien, nomor RM, keterangan berapa kali makan, dan kebutuhan khusus seperti permintaan nasi biasa, nasi tim, alergi, dan lainnya. Berdasarkan buku tersebut, ahli gizi membuat daftar perencanaan belanja bahan dapur rangkap 2 sesuai menu dan jumlah pasien. Rincian kebutuhan belanja bahan dapur dibuat untuk persediaan bahan makanan 2 hari ke depan dan jika melewati tanggal merah maka pemesanan bisa untuk 4 hari ke depan. Kebutuhan belanja bahan dapur disusun berdasarkan buku resep (1 resep untuk 3 porsi) sesuai menu yang sudah ditetapkan. Biasanya ahli gizi sedikit melebihkan jumlah porsi dari data pesanan makan sebagai cadangan apabila ada pasien baru datang dan menggunakan rata-rata pasien per hari untuk mengestimasi jumlah pasien hari berikutnya guna menetapkan belanja bahan dapur. Apabila sudah membuat daftar belanja rangkap 2, maka rangkap 1 diberikan kepada pedagang sebagai formulir pemesanan, dan rangkap 2 untuk arsip ahli gizi.

2) Proses pemesanan bahan makanan:

Daftar belanja yang merupakan formulir pemesanan (rangkap 1) diberikan kepada pihak rekanan (pedagang sayur keliling) ketika pedagang datang untuk memberikan pesanan belanja sebelumnya. Formulir pemesanan rangkap 2 disimpan oleh ahli gizi untuk digunakan sebagai checklist ketika barang datang. Ahli gizi menetapkan waktu penerimaan bahan makanan yaitu 2 hari setelah pedagang menerima formulir pemesanan dan 4 hari apabila melewati tanggal merah.

3) Proses pembelian bahan makanan:

Pedagang menyediakan sayur sesuai pesanan dan diantar ke RS. Formulir pemesanan rangkap 1 oleh pedagang sayur diberikan kepada Bagian Pengadaan. Sayur sesuai pesanan dihitung oleh pedagang dan diawasi secara langsung oleh Bagian Pengadaan. Apabila barang yang dipesan tidak terpenuhi, maka ahli gizi langsung menentukan sayur pengganti. Pedagang menimbang berat sayur tidak dengan timbangan namun menggunakan tangan. Setelah ditimbang, pedagang menyebutkan harga sayur tersebut dan Bagian Pengadaan mencatatnya di dalam formulir pemesanan sekaligus melakukan proses checklist.

4) Proses penerimaan bahan makanan:

Setelah harga sayur dicatat oleh Bagian Pengadaan, pedagang memberikan sayur tersebut kepada ahli gizi melalui pintu terima. Ahli gizi melakukan proses checklist penerimaan barang dan tidak selalu menimbang ulang berat sayur apakah telah sesuai dengan pesanan. Setelah diterima dan di checklist, sayur-sayur tersebut dikumpulkan dan siap untuk dipotong atau diolah. Masing-masing sayur dimasukkan ke dalam plastik dan diberi keterangan tanggal guna mengetahui sayur mana yang harus diolah terlebih dahulu untuk menghindari kebusukan, lalu dimasukkan ke dalam lemari pendingin.

5) Proses pengolahan bahan makanan:

Petugas dapur menyiapkan buku resep. Ahli gizi menghitung kebutuhan lauk pauk (daging/ayam/ikan/telor/tahu/tempe, dll) dengan cara mengalikan porsi dengan jumlah pasien yang ada, memisahkan bahan makanan dan petugas dapur mulai membersihkan serta memotong sayuran. Ahli gizi memisahkan lauk pauk untuk pasien alergi, pasien tanpa diet dengan pasien diet khusus seperti RG (rendah garam) dan DM (diabetes mellittus). Sayur dan lauk pauk yang sudah dipersiapkan siap untuk dimasak. Apabila sudah matang, siap untuk dibagikan ke piring-piring pasien (diporsi)

6) Proses pendistribusian makanan pasien:

Petugas dapur melihat buku pesanan makan pasien untuk memastikan nama dan jenis diet pasien agar tidak salah meyiapkan makanannya. Petugas dapur membagikan makanan ke masingmasing piring pasien sesuai daftar buku pesanan dan menutupnya dengan plastik kemas. Setelah makanan pasien siap 1 set, maka akan diberi label nama pasien dan diletakkan pada kereta dorong petugas dapur untuk siap diantar ke kamar pasien.

7) Proses penyajian makanan pasien:

Petugas dapur mengantar ke kamar pasien sesuai dengan daftar buku makan pasien dan diet pasien. Petugas dapur memberikan kembali Buku Makan dan Minum pasien kepada perawat jaga tiap lantai dan menanyakan apakah ada pasien baru yang memerlukan diet baru/makan atau ada pasien yang puasa laborat/puasa operasi. Lalu petugas dapur membawa baki makan pasien ke ruang rawat.

Berdasarkan hasil dokumentasi POS yang diterbitkan tahun 2015 dengan pelaksanaan POS pada saat ini di tahun 2017 banyak mengalami perubahan. Dari hasil uraian tersebut terlihat bahwa proses pelaksanaan per aktivitas lebih detail dibandingkan dengan uraian POS yang sudah ada. Hal ini dikarenakan banyaknya penyesuaian dan pembaruan pelaksanaan POS namun tidak diimbangi dengan pembaruan dokumen. 


\section{Pengumpulan Dokumen}

Tabel 1 berikut ini berisi kumpulan dokumen yang terkait pada unit gizi masing-masing aktivitas:

Tabel 1. Kumpulan Dokumen Tiap Aktivitas

\begin{tabular}{|c|c|c|c|}
\hline \multirow[b]{2}{*}{$\begin{array}{c}\text { Nama } \\
\text { Aktivitas }\end{array}$} & \multicolumn{3}{|c|}{ Dokumen Terkait } \\
\hline & $\begin{array}{c}\text { Nama } \\
\text { Dokumen }\end{array}$ & Ada & Tidak \\
\hline $\begin{array}{l}\text { Penyelengga- } \\
\text { raan Makanan } \\
\text { dan Perenca- } \\
\text { naan Kebutu- } \\
\text { han Makanan }\end{array}$ & $\begin{array}{l}\text { Buku Makan } \\
\text { dan Diet Pasien } \\
\text { Bon Permintaan } \\
\text { Makanan } \\
\begin{array}{l}\text { Formulir } \\
\text { kebutuhan } \\
\text { makanan }\end{array} \\
\begin{array}{l}\text { Daftar siklus } \\
\text { menu pasien }\end{array} \\
\begin{array}{l}\text { Daftar siklus } \\
\text { menu perawat }\end{array} \\
\text { Spesifikasi } \\
\text { bahan makanan } \\
\text { Buku Resep }\end{array}$ & $\begin{array}{l}\sqrt{ } \\
\sqrt{ } \\
\sqrt{ }\end{array}$ & $\sqrt{ }$ \\
\hline $\begin{array}{l}\text { Proses } \\
\text { pemesanan } \\
\text { bahan } \\
\text { makanan, } \\
\text { proses } \\
\text { pembelian } \\
\text { bahan } \\
\text { makanan, } \\
\text { proses } \\
\text { penerimaan } \\
\text { bahan } \\
\text { makanan }\end{array}$ & $\begin{array}{l}\text { Form } \\
\text { permintaan / } \\
\text { daftar } \\
\text { perencanaan } \\
\text { belanja bahan } \\
\text { dapur } \\
\text { (rangkap 1) }\end{array}$ & $\sqrt{ }$ & \\
\hline & $\begin{array}{l}\text { Form } \\
\text { permintaan / } \\
\text { daftar } \\
\text { perencanaan } \\
\text { belanja bahan } \\
\text { dapur } \\
\text { (rangkap 2) }\end{array}$ & $\sqrt{ }$ & \\
\hline
\end{tabular}

Pada kolom jenis lainnya terdapat Buku Rekap Makan Pasien yang dibuat oleh ahli gizi setiap hari. Buku tersebut berisi jumlah porsi hewani, nabati, dan sayur hasil olahan untuk masing-masing pasien, perawat, penjaga pasien, dan rohaniwan lainnya yang juga bertugas dan

\begin{tabular}{|l|l|c|c|}
\hline \multirow{2}{*}{$\begin{array}{c}\text { Nama } \\
\text { Aktivitas }\end{array}$} & \multicolumn{3}{|c|}{ Dokumen Terkait } \\
\cline { 2 - 4 } & $\begin{array}{c}\text { Nama } \\
\text { Dokumen }\end{array}$ & Ada & Tidak \\
\hline $\begin{array}{l}\text { Prosedur } \\
\text { Pendistribusia } \\
\text { n Makanan }\end{array}$ & $\begin{array}{l}\text { Buku laporan } \\
\text { ketepatan wak- } \\
\text { tu pendistribu- } \\
\text { sian makanan }\end{array}$ & $\sqrt{ }$ & \\
\hline Lainnya & $\begin{array}{l}\text { Buku Rekap } \\
\text { Makan Pasien }\end{array}$ & $\sqrt{ }$ & \\
\hline & $\begin{array}{l}\text { Buku laporan } \\
\text { harian } \\
\text { pemakaian } \\
\text { bahan baku } \\
\text { dan jumlah } \\
\text { porsi jun }\end{array}$ & $\sqrt{ }$ \\
\hline
\end{tabular}

bertempat tinggal di RS tersebut. Sedangkan untuk buku Laporan Pemakaian Bahan Baku beserta Jumlah Porsi harian ialah laporan yang diminta oleh manajemen yang baru namun belum tersedia karena dokumen tidak tercantum pada POS yang ada, sehingga karena kebutuhan manajemen akan informasi tersebut belum terpenuhi maka dapat mempengaruhi pengambilan keputusan oleh manajemen terkait dengan pentingnya kegunaan informasi pada laporan tersebut.

\section{CONCLUSION, SUGGESTION, AND LIMI- TATION}

Berdasarkan hasil penelitian, maka dapat disimpulkan bahwa: pertama, adanya banyak perubahan dan penyesuaian dalam pelaksanaan operasional sehari-hari tanpa diimbangi dengan pembaruan prosedur POS dinilai kurang baik. Hal ini mengakibatkan adanya ketidaksesuaian antara pelaksanaan dengan POS meskipun pelaksanaannya lebih detail dan teratur dibandingkan dengan POS nya. Kedua, hasil evaluasi POS ditemukan adanya laporan yang diminta oleh manajemen baru namun belum tersedia pada unit gizi karena dokumen tersebut tidak tercantum pada POS yang ada. Hal tersebut mempengaruhi pengambilan keputusan manajemen sehingga perlu dilakukan pembaruan POS.

Berdasarkan kesimpulan tersebut, maka disarankan untuk melakukan pembaruan POS dengan memperhatikan kebutuhan akan laporan 
dari manajemen baru RS X dan menyesuaikan dengan perubahan-perubahan yang terjadi sesuai situasi / kondisi perkembangan RS X saat ini. Sedangkan untuk saran bagi peneliti selanjutnya, dapat menggunakan sudut pandang perubahan regulasi atau pergantian software rumah sakit dalam mengevaluasi dan pembaruan POS.

Keterbatasan pada penelitian ini yaitu perubahan POS hanya diambil dari sudut pandang perubahan manajemen. Namun perubahan POS juga dapat dipengaruhi oleh adanya perubahan regulasi rumah sakit ataupun pergantian software rumah sakit.

\section{REFERENCES}

Bodnar, G. H. dan Hopwood, W. S., 2013, Accounting Information Systems $11^{\text {th }}$ Ed, New Jersey: Pearson Education Inc.

Fatimah, E. N., 2015, Strategi Pintar Menyusun POS (Standard Operating Procedure), Yogyakarta: Pustaka Baru Press.

Marbun, S. H., 2013, Peran Gaya Kepemimpinan terhadap Lingkungan Pengendalian dalam Struktur dan Pelaksanaan Standard Operating Procedure (SOP) di Rumah Sakit, vol. 2, no. 2, Universitas Surabaya.

Purba, M. P., 2014, Pengadaan Barang Dan Jasa BUMN, Yogyakarta: Graha Ilmu.

Purnamasari, E. P., 2015, Panduan Menyusun POS, Yogyakarta: Kobis.

Rahman, Abdul Saleh, 2003, Manual Prosedur Operasional Standar, Perpustakaan Universitas Indonesia, Depok.

Soemohadiwidjojo, A. T., 2015, Mudah Menyusun POS, Jakarta: Penebar Plus.

Tambunan Rudi M., 2008, Standard Operating Procedures (POS), Jakarta: Maiestas Publishing.

Undang-Undang Republik Indonesia Nomor 44 Tahun 2009 tentang Rumah Sakit (http://www.depkes.go.id/resources/down load/peraturan/UU\%20No. $\% 2044 \% 20$ Th $\% 2$ 02009\%20ttg\%20Rumah\%20Sakit.PDF diunduh 22 Desember 2017).

Windya Y. dan Kurniawati E., Evaluasi Penerapan Prosedur Operasional Standar Pengelolaan Keuangan Daerah di Provinsi Papua, Fakultas Ekonomika dan Bisnis, Universitas Satya Wacana.

Budijanto D., 2017, Data dan Informasi Profil Kesehatan Indonesia, Jakarta (http://www.depkes.go.id/resources/down load/pusdatin/lain-

lain/Data\%20dan\%20Informasi\%20Kesehata n\%20Profil\%20Kesehatan\%20Indonesia\%202 016\%20-\%20\%20smaller\%20size \%20-

\%20web.pdf , diunduh 22 Desember 2017).

Zulfikar, M. A., 2012, Sistem Informasi Simpan Pinjam pada Koperasi "KOPKA" Temanggung, Skripsi Strata Satu Dipublikasikan, Yogyakarta, Sekolah Tinggi Manajemen Informatika Dan Komputer Amikom. 